\title{
PENGUJIAN DAYA DUKUNG PERKERASAN JALAN DENGAN DYNAMIC CONE PENETROMETER (DCP) SEBAGAI STANDAR UNTUK EVALUASI PERKERASAN JALAN
}

\author{
A. Tatang Dachlan
}

\begin{abstract}
Abstrak
Faktor penting dalam perencanaan pemeliharaan dan peningkatan jalan antara lain adalah data kekuatan tanah dasar, sifat-sifat bahan, komposisi dan tebal lapis perkerasan yang ada. Kekuatan tanah dasar yang ada di lapangan seperti nilai California Bearing Ratio (CBR) tergantung pada kondisi pada saat pelaksanaan dan selama operasi pelayanan berlangsung. Kerusakan jalan yang selama ini sering dijumpai, fakta mahalnya pengumpulan data CBR dan kendala lambannya upaya pemeliharaan memberikan sumbangan makin parahnya kondisi perkerasan yang sering dilalui oleh lalu lintas sebagai penggerak ekonomi rakyat. Untuk mendapatkan data tersebut di atas, telah diperkenalkan alat Penetrasi Konus Dinamis (Dynamic Cone Penetrometer), yaitu suatu alat yang dirancang untuk menguji kekuatan lapisan granular dan tanah dasar perkerasan jalan secara cepat. Lapis perkerasan dimaksud adalah pondasi granular, stabilisasi tanah, termasuk tanah dasar. Pengujian dilakukan menerus sampai kedalaman $80 \mathrm{~cm}$ dan bila perlu dapat diperdalam dengan menyambung tangkai pengukur sampai kedalaman $120 \mathrm{~cm}$. Dalam sepuluh tahun terakhir, DCP telah banyak digunakan dalam memperoleh data CBR untuk perencanaan perkerasan jalan sehingga sudah saatnya metode DCP dapat dijadikan standar uji di Indonesia.
\end{abstract}

Kata kunci: DCP, CBR

\section{Abstract}

The important factors for betterment and maintenance of roads design among other things are data of sub grade strength, materials properties, existing composition and layer thickness. Sub grade strength in the field such as California Bearing Ratio (CBR) value depends on the condition during construction and during operation services. The road deterioration of this is now being frequently happened, the fact of costly data collection, and the problem of late maintenance arise give a contribution to be worst of road condition, where public economic movement are trafficked. To achieve these data, a Dynamic Cone Penetrometer has been introduced that is an equipment for testing the strength of granular layers and sub grade or road pavement rapidly. This aims pavement layers are granular base, soil stabilization, including subgrade. The testing procedures is performed continuously until $80 \mathrm{~cm}$ depth, and if necessary to be deepen by extending the steel bar measurement to reach $120 \mathrm{~cm}$ depth. In the last ten years, DCP has been applied to achieve CBR data for road pavement design, so the time is coming for DCP testing method to be a standard testing in Indonesia.

Key words: DCP, CBR

\section{PENDAHULUAN}

\subsection{Masalah Perencanaan Jalan di Indonesia}

Pada umumnya perencanaan jalan di Indonesia khususnya di lingkungan Departemen Pekerjaan Umum dan Dinas Pekerjaan Umum di daerah menggunakan nilai CBR (California Bearing Ratio) dalam menentukan tebal perkerasan berdasarkan proyeksi lalu lintas dan umur rencananya. Data CBR dapat digunakan untuk mengevaluasi perlunya pemeliharaan dan peningkatan jalan. Dalam upaya mendapatkan data CBR di lapangan, dapat dilakukan penentuan nilai CBR di tempat (in situ) secara konvensional (SNI 03-1738-1989), namun cara ini memerlukan waktu yang relatif lama dan peralatan CBR Laboratorium yang relatif mahal (SNI 03-1744-1089). Cara lain yang relatif baru tetapi sudah diterapkan di lapangan adalah dengan alat Dynamic Cone Penetrometer (DCP).

\subsection{Dasar Teori DCP dan Perkembangan untuk Perencanaan}

Alat DCP terdiri atas tangkai baja yang di bagian ujung dipasang konus baja dengan ukuran dan sudut tertentu, dan di bagian atas dilengkapi dengan batang pengarah jatuh palu penumbuk. Metode DCP ini adalah cara pengujian kekuatan lapisan perkerasan jalan (tanah dasar, pondasi bahan berbutir) yang relatif cepat, yaitu dengan menekan ujung konus yang ditimbulkan oleh pukulan palu dengan beban dan tinggi jatuh tertentu menerus sampai kedalaman tertentu. 
Untuk memperkirakan nilai CBR tanah atau bahan granular dapat menggunakan beberapa metode, namun yang cukup akurat dan paling murah sampai saat ini adalah dengan alat Penetrasi Konus Dinamis atau dikenal dengan nama Dynamic Cone Penetrometer (DCP). Di samping itu DCP adalah salah satu cara pengujian tanpa merusak atau Non Destructive Testing (NDT), yang digunakan untuk lapis pondasi batu pecah, pondasi bawah sirtu, stabilisasi tanah dengan semen atau kapur dan tanah dasar.

- Van Vuuren, 1969, (Konus 60 )

- Kleyn \& Harden, 1983 , (Konus 30²)

- Smith dan Pratt, 1983 , (Konus 30²)

- TRL, Road Note 8, 1990, (Konus 60²)

\subsection{DCP di Indonesia}

Sampai saat ini alat DCP yang sudah banyak dikenal dan digunakan adalah DCP yang diperkenalkan oleh TRL yang dilaporkan pada Overseas Road Note 31, Crowthorne, UK (1993), untuk kondisi tropis dan sub-tropis. Grafik hubungan yang digunakan adalah perumusan dari Smith dan Pratt, 1983 untuk sudut konus $30^{\circ}$ dengan persamaan Log CBR = 2,503 - 1,15(Log DCP), dan TRL, 1990 untuk sudut konus $60^{\circ}$ dengan persamaan Log CBR = 2,48 - 1,057(Log DCP).

Pada umumnya setiap rangkaian pengujian perkerasan jalan dengan alat DCP diiringi dengan pengujian tebal lapis perkerasan (test pits) di beberapa tempat yang dianggap mewakili suatu segmen jalan yang diuji.

\subsection{Tujuan Pengkajian}

Maksud tulisan ini adalah mengkaji perkembangan penggunaan DCP yang selama ini sudah banyak digunakan untuk perencanaan dan pemeliharaan jalan di Indonesia. Dengan memberlakukan pengujian DCP di Indonesia sebagai standar dalam merancang pembangunan dan pemeliharaan jalan, maka diharapkan dapat dicapai efektifitas pengumpulan data yang sederhana dan efisien.

\section{KERANGKA DASAR PEMIKIRAN}

Pengujian menggunaan alat DCP pada lapis perkerasan jalan tanpa pengikat meliputi pondasi
Beberapa organisasi internasional mempunyai beberapa jenis alat pengukur daya dukung tanah dan dibuat korelasi antara hasil pengukuran alat DCP dengan pengukuran daya dukung tanah yang lain.

Transport Road Research (TRL, 1993), mengembangkan prosedur pengujian lapis perkerasan dengan DCP, dan dilaporkan dalam Overseas Road Note 31 (1993) menggunakan hubungan sebagai berikut: batu pecah (bahan berbutir), stabilisasi tanah dengan semen atau kapur, dan tanah dasar. Hasil uji DCP diplotkan secara grafis dan dianalisis untuk menentukan nilai CBR, serta tebal setiap lapisan dibandingkan dengan tebal hasil pengukuran dengan lubang uji (test pits).

Test pits pada umumnya dilakukan dengan cara menggali lapis perkerasan berukuran $60 \mathrm{~cm}$ x $60 \mathrm{~cm}$ menggunakan pemotong lapisan perkerasan atau linggis dan alat lainnya, dengan maksud untuk mengetahui tebal lapisan perkerasan granular sampai mencapai tanah dasar.

Dengan membandingkan data hasil uji DCP dan persyaratan CBR yang direncanakan dalam spesifikasi, maka dapat diketahui kesesuaian dengan spesifikasi dan dapat diukur risiko penerimaan berdasarkan data tersebut. Dengan membandingkan terhadap pengujian CBR lapangan konvensional, dapat diketahui efektifitas pengujian.

Pada uraian berikut disajikan rangkuman prosedur pengujian DCP yang disusun untuk rancangan standar.

\section{PENGAMBILAN CONTOH}

\subsection{Pengumpulan Data}

Data adalah diperoleh dari hasil penyelidikan di jalan pantai utara Jawa (Puslitbang Prasarana Transportasi, 2002). Penyelidikan meliputi pengambilan contoh inti (core drilled), pengujian DCP dan test pits. Lihat Tabel 1. 
Tabel 1 Jumlah Titik Uji

\begin{tabular}{|c|l|c|c|c|c|c|}
\hline No & Kode Proyek & Lokasi Proyek & $\begin{array}{c}\text { Panjang Jalan } \\
(\mathbf{m})\end{array}$ & $\begin{array}{c}\text { Jumlah } \\
\text { Sampel (n) }\end{array}$ & $\begin{array}{c}\text { Jumlah Core } \\
\text { drill dan DCP }\end{array}$ & $\begin{array}{c}\text { Jumlah } \\
\text { Test Pits }\end{array}$ \\
\hline 1. & AP04 & JP-1 & 10.300 & 22 & 19 & 3 \\
\hline 2. & AP05 & JP-2 & 11.009 & 22 & 18 & 4 \\
\hline 3. & AP06 & PC & 10.734 & 26 & 23 & 3 \\
\hline \multicolumn{5}{|r|}{ Jumlah } & 60 & 10 \\
\hline
\end{tabular}

Penentuan titik untuik lokasi pengambilan contoh uji menggunakan cara random sampling, sesuai dengan SNI 03-6868-2002, Tata Cara Pengambilan Contoh Uji Secara Acak untuk Bahan-bahan Konstruksi.

Data lainnya diambil dari Laporan Hasil Pengujian, Pekerjaan Peningkatan Jalan North Java Road Improvement Project (NJRIP). Paket AP-04, AP-05 dan AP-06. Jawa Barat. Bandung, (Puslitbang Prasarana Transportasi, Oktober 2002).

\section{METODE PENGUJIAN DCP}

\subsection{Ruang Lingkup}

Metode ini menetapkan cara pengujian kekuatan lapisan perkerasan jalan tanpa pengikat (tanah dasar, pondasi bahan berbutir) secara cepat menggunakan alat Penetrasi Konus Dinamis (Dynamic Cone Penetrometer). Pengujian dilakukan dengan menekan ujung konus terbuat dari baja dengan ukuran dan sudut tertentu. Tekanan konus ditimbulkan oleh pukulan palu dengan beban dan tinggi jatuh tertentu menerus sampai kedalaman $80 \mathrm{~cm}$ dan bila perlu dapat diperdalam dengan menyambung tangkai pengukur sampai kedalaman $120 \mathrm{~cm}$.

\subsection{Acuan Normatif}

SNI 03-1738-1989, Metode Pengujian CBR Lapangan

SNI 03-1744-1989, Metode Pengujian CBR Laboratorium

SNI 03-4153-1996, Metode pengujian penetrasi dengan standar penetration tests (SPT)

Overseas Road Note 31 (1993). A guide to the structural design of bitumen-surfaced roads in tropical and sub-tropical countries. Transport Research Laboratory. United Kingdom

Austroads (1992). Pavement Design. A Guide to the structural design of roads pavements.

\subsection{Kegunaan}

Hasil pengujian DCP ini dikorelasikan dengan nilai CBR (California Bearing Ratio) untuk keperluan perencanaan pemeliharaan dan peningkatan jalan termasuk perencanaan tebal perkerasan jalan.

\subsection{Peralatan dan Teknisi}

\subsubsection{Umum}

a) Batang penyambung peralatan DCP harus dipasang dengan kokoh dan kaku untuk menghindari kerusakan atau patahnya tangkai penyambung;

b) Pengujian tidak boleh dilaksanakan pada saat hujan atau lapis perkerasan tergenang air;

\subsubsection{Peralatan}

Peralatan penetrasi konus dinamis meliputi tiga bagian utama yang satu sama lain harus disambung sehingga cukup kaku.

Lihat Gambar 1.

\subsubsection{Personil}

Pengujian DCP memerlukan 3 orang teknisi atau operator, yaitu:

1) Satu orang memegang peralatan yang sudah terpasang dengan tegak;

2) Satu orang untuk mengangkat dan menjatuhkan palu;

3) Satu orang untuk mencatat hasil.

\subsection{Cara Pengujian}

a. Sambungkan seluruh bagian peralatan dan pastikan bahwa sambungan tangkai atas dengan landasan serta tangkai bawah dan kerucut baja sudah tersambung dengan kokoh;

b. Pegang alat yang sudah terpasang pada posisi tegak di atas dasar yang rata dan 
stabil, kemudian catat pembacaan nol sebagai pembacaan awal pada mistar

pengukur kedalaman.

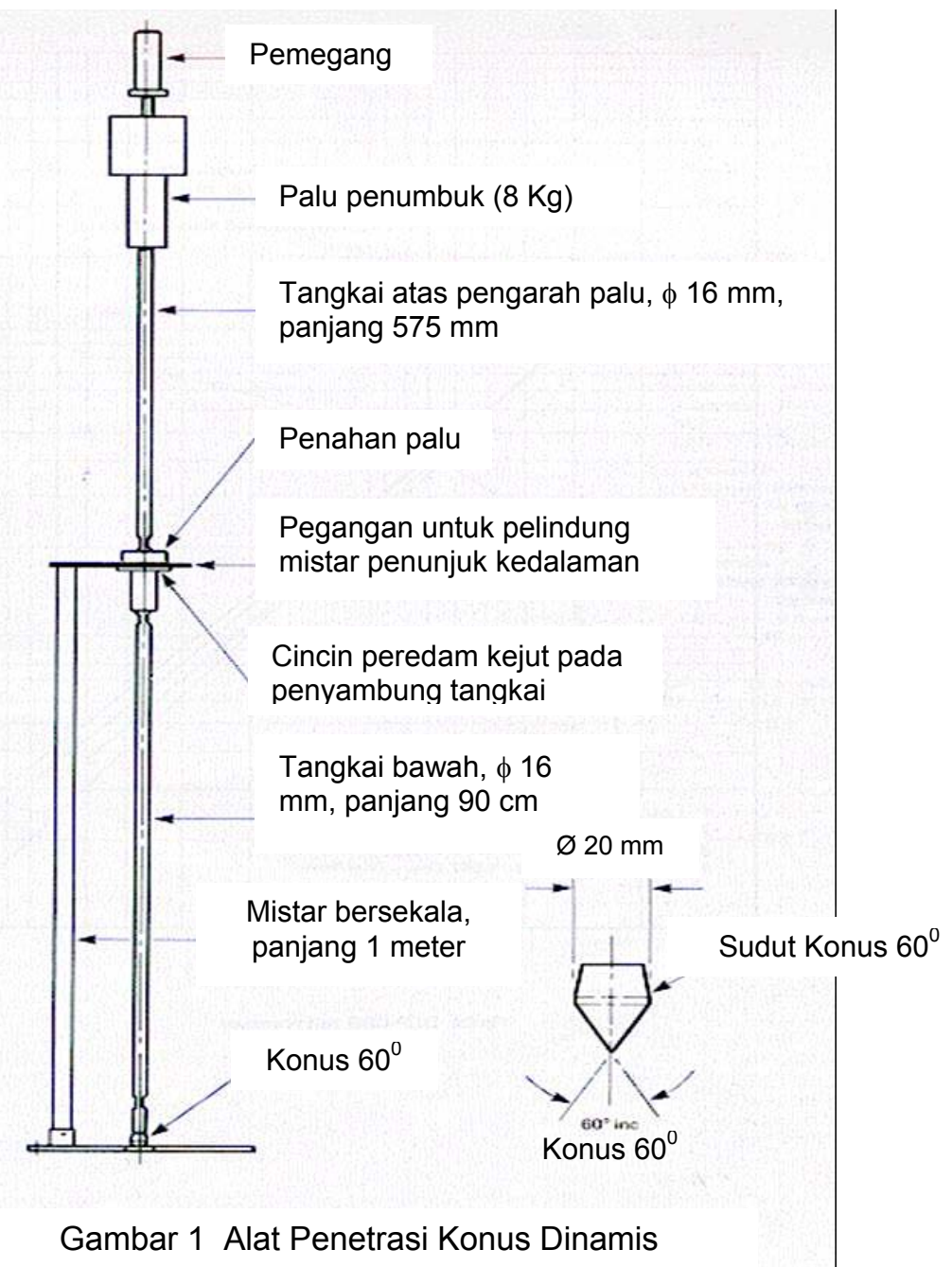

c. Cara mengangkat dan menjatuhkan palu serta jumlah pukulan

1) Angkat palu pada tangkai bagian atas dengan hati-hati sehingga menyentuh batas handel;

2) Lepaskan palu sehingga jatuh bebas dan tertahan pada landasan.

3) Lakukan langkah-langkah pada Butir 1) dan 2) di atas sesuai ketentuanketentuan sebagai berikut:

- Untuk lapisan perkerasan yang normal, pencatatan dilakukan pada setiap kedalaman $10 \mathrm{~mm}$; walaupun demikian, masih memungkinkan mengubah jumlah pukulan antara pembacaan bila kekuatan lapisan yang diuji berubah lebih keras;
- Untuk pondasi yang terbuat dari bahan berbutir yang cukup keras, maka harus dilakukan pembacaan kedalaman pada setiap 5 sampai 10 pukulan;

- Untuk pondasi bawah atau tanah dasar yang terbuat dari bahan yang tidak keras maka pembacaan kedalaman pada sudah cukup untuk setiap 1 atau 2 pukulan.

4) Apabila kecepatan penetrasi kurang dari $0,5 \mathrm{~mm} /$ pukulan, pembacaan masih dibenarkan tetapi bila setelah 20 pukulan tidak menunjukkan adanya penurunan, maka pengujian harus dihentikan. Selanjutnya lakukan pengeboran atau penggalian pada bagian tersebut sampai mencapai bagian yang dapat diuji kembali. 
d. Cara mengangkat tangkai dan peralatan DCP

1) Siapkan bahwa peralatan akan diangkat atau dicabut ke atas;

2) Angkat palu dan pukulkan beberapa kali dengan arah ke atas sehingga menyentuh handel dan tangkai bawah terangkat ke atas permukaan tanah.

\subsection{Menentukan Nilai CBR}

a. Pencatatan hasil pengujian dilakukan menggunakan Formulir 1-DCP.

b. Periksa hasil pengujian lapangan yang terdapat pada formulir dan hitung akumulasi jumlah pukulan dan akumulasi penetrasi setelah dikurangi pembacaan awal pada Formulir-2 DCP; (dalam Tabel 2 disajikan analisis pengujian DCP)

c. Gunakan Formulir 3-DCP, berbentuk sumbu tegak dan sumbu datar, di mana pada bagian tegak menunjukkan kedalaman penetrasi dan arah horizontal menunjukkan jumlah pukulan; (dalam Gambar 2 disajikan tipikal ploting data DCP dan CBR)

d. Plotkan hasil pengujian lapangan pada salib sumbu di atas;

e. Tarik garis yang mewakili titik-titik koordinat tertentu yang menunjukkan lapisan yang relatif seragam;

f. Hitung kedalaman lapisan yang mewakili titik-titik tersebut, yaitu selisih antara perpotongan garis-garis yang dibuat pada Butir 4), dalam satuan mm;

g. Hitung kecepatan penetrasi untuk setiap pukulan (mm/pukulan);

h. Gunakan gambar grafik pada Formulir-4 DCP (Gambar 3) dengan cara menarik nilai kecepatan penetrasi pada sumbu horizontal ke atas sehingga memotong garis tebal untuk sudut konus 600 atau garis patah-patah untuk sudut konus 300 ;

i. Tarik garis dari titik potong tersebut ke arah kiri sehingga nilai CBR dapat diketahui.

Tabel 2 Tipikal Pengolahan Data Dcp (Form-2 Dcp)

Lokasi

Nomor Titik Uji

Pembacaan Awal (pada mistar)

Awal pengujian pada Lapisan
: Cirebon - Palimanan

: TP-2

: $146 \mathrm{~mm}$

: Pondasi agregat $A$
Tanggal : 24 September 2002

Petugas : Paijo

\begin{tabular}{|c|c|c|c|c|c|c|c|c|}
\hline No & Pukulan & $\begin{array}{c}\text { Penetrasi } \\
\text { Kedalama } \\
\mathbf{n} \\
(\mathrm{mm})\end{array}$ & $\begin{array}{l}\text { Kumulasi } \\
\text { Jumlah } \\
\text { Pukulan }\end{array}$ & Elevasi & $\begin{array}{l}\text { Tebal } \\
(\mathrm{mm})\end{array}$ & $\begin{array}{c}\text { DCP } \\
\text { (mm/pukulan }\end{array}$ & $\begin{array}{c}\text { CBR } \\
(\%)\end{array}$ & Keterangan \\
\hline $\mathbf{a}$ & b & c & d & e & $f$ & g & $\mathbf{h}$ & $\mathbf{i}$ \\
\hline 1 & 0 & 65 & 0 & 146 & & & & AC-Binder, $146 \mathrm{~mm}$ \\
\hline 2 & 5 & 106 & 5 & 187 & & & & \multirow{9}{*}{$\begin{array}{l}\text { Agg A, } 121,6 \mathrm{~mm} \text {, El: } \\
267,6 \mathrm{~mm}\end{array}$} \\
\hline 3 & 5 & 139 & 10 & 220 & & & & \\
\hline 4 & 5 & 167 & 15 & 248 & & & & \\
\hline 5 & 5 & 200 & 20 & 281 & & & & \\
\hline 6 & 5 & 239 & 25 & 320 & & & & \\
\hline 7 & 5 & 262 & 30 & 343 & & & & \\
\hline 8 & 5 & 277 & 35 & 358 & 212 & 6,1 & 45,0 & \\
\hline 9 & 5 & 300 & 40 & 381 & & & & \\
\hline 10 & 5 & 329 & 45 & 410 & & & & \\
\hline 11 & 5 & 355 & 50 & 436 & & & & \multirow{10}{*}{$\begin{array}{l}\text { Agg B, } 318 \text { mm, El: } \\
585 \text { mm }\end{array}$} \\
\hline 12 & 5 & 370 & 55 & 451 & & & & \\
\hline 13 & 5 & 381 & 60 & 462 & & & & \\
\hline 14 & 5 & 398 & 65 & 479 & & & & \\
\hline 15 & 5 & 416 & 70 & 497 & & & & \\
\hline 16 & 5 & 440 & 75 & 521 & 163 & 4,1 & 68,4 & \\
\hline 17 & 5 & 515 & 80 & 596 & & & & \\
\hline 18 & 3 & 581 & 83 & 662 & & & & \\
\hline 19 & 3 & 625 & 86 & 706 & & & & \\
\hline 20 & 3 & 664 & 89 & 745 & & & & \\
\hline
\end{tabular}




\begin{tabular}{|c|c|c|c|c|c|c|c|c|}
\hline No & Pukulan & $\begin{array}{c}\text { Penetrasi } \\
\text { Kedalama } \\
\mathbf{n} \\
(\mathrm{mm})\end{array}$ & $\begin{array}{c}\text { Kumulasi } \\
\text { Jumlah } \\
\text { Pukulan }\end{array}$ & Elevasi & $\begin{array}{l}\text { Tebal } \\
(\mathrm{mm})\end{array}$ & $\begin{array}{c}\text { DCP } \\
\text { (mm/pukulan }\end{array}$ & $\begin{array}{l}\text { CBR } \\
(\%)\end{array}$ & Keterangan \\
\hline$a$ & b & C & d & e & $f$ & g & $\mathbf{h}$ & $\mathbf{i}$ \\
\hline 21 & 3 & 715 & 92 & 796 & & & & \multirow{4}{*}{$\begin{array}{l}\text { Selected Embankment, } \\
\text { El: } 1014 \mathrm{~mm}\end{array}$} \\
\hline 22 & 3 & 783 & 95 & 864 & & & & \\
\hline 23 & 3 & 864 & 98 & 945 & & & & \\
\hline 24 & 3 & 933 & 101 & 1014 & 218 & 24,2 & 10,4 & \\
\hline
\end{tabular}

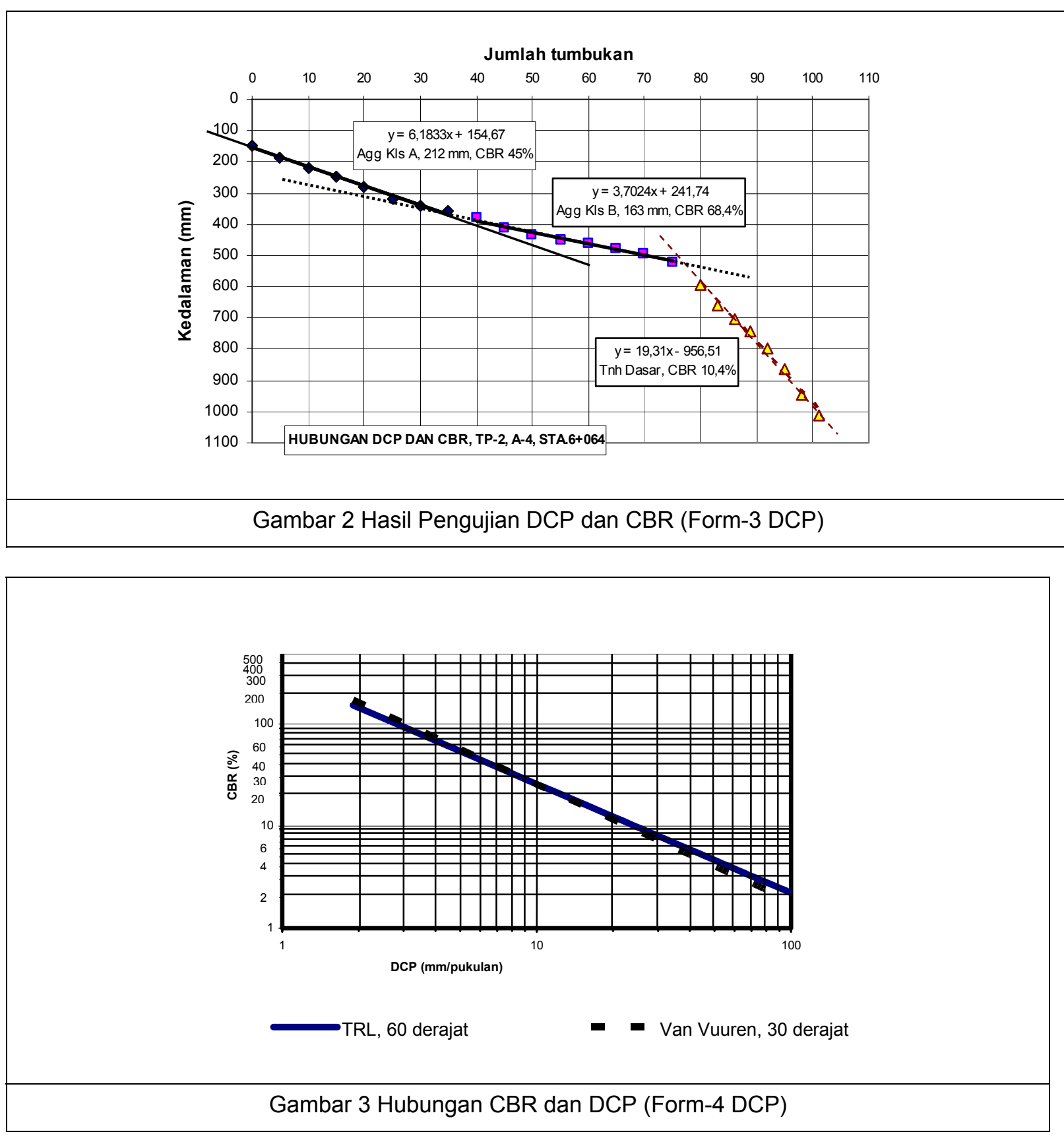




\section{ANALISIS DAN PEMBAHASAN}

\subsection{Efektifitas Prinsip Kerja DCP}

Prinsip kerja DCP adalah bahwa kecepatan penetrasi dari konus ketika ditekan oleh kekuatan standar, sebanding dengan kekuatan bahan yang diukur. Bila lapis perkerasan jalan memiliki kekuatan yang berbeda, lingkungan lapisan-lapisan di sekitarnya dapat diidentifikasi dan ketebalan lapisan dapat ditentukan. Contohnya adalah pengujian CBR di laboratorium menggunakan peralatan mekanis.

Pada umumnya pengujian CBR lapangan konvensional menggunakan beban truk atau tripod menghasilkan jumlah data sekitar 3 sampai 4 hasil uji per hari, karena memerlukan waktu untuk menggali perkerasan jalan ukuran $60 \mathrm{~cm}$ x $60 \mathrm{~cm}$, memasang jack CBR di bawah sasis truk, selanjutnya proses pengujian. Pengujian ini hanya dapat dilakukan pada satu lapis perkerasan saja. Untuk lapis lainnya harus memperluas dan memperdalam penggalian sehingga dapat merusak perkerasan yang ada (destructive).

Berdasarkan pengalaman lapangan, hasil pengujian dengan alat DCP dapat dicapai sekitar 10 sampai 12 hasil uji per hari untuk 3 lapisan atau lebih, sehingga pengujian denagn DCP adalah 6 sampai 8 kali lebih cepat dari pada pengujian CBR lapangan konvensional.

\subsection{Contoh Hasil Uji dengan Alat DCP}

Dari Gambar 2 terlihat hubungan jumlah tumbukan atau pukulan pada sumbu mendatar dan kedalaman pada sumbu vertikal. Titik-titik hasil uji dibagi dalam beberapa segmen yang diperkirakan seragam atau dapat ditarik garis lurus. Dengan menggunakan program Excel dalam komputer dengan mudah dapat dibuat suatu persamaan garis lurus melalui menu trendline. Dari Gambar 2 terlihat bahwa makin datar garis representasi makin tinggi nilai CBR. Sebaliknya makin tegak garis representasi nilai CBR makin kecil.

Dalam Gambar 4 diperlihatkan spesifikasi tebal perkerasan dan nilai CBR, serta hasil uji DCP dan test pits. Hasil uji DCP memperlihatkan nilai CBR agregat-A $45 \%$; 212 $\mathrm{mm}$, CBR Agregat-B 68,4 \%, 163 mm, Selected material CBR 10,8 \%, $218 \mathrm{~mm}$, dibawah lapisan tersebut sudah keras dan tidak dapat ditembus konus. Sementara spesifikasi mensyaratkan CBR $80 \%, 360$ mm, CBR agregat-B $60 \% 250$ $\mathrm{mm}$, selected material CBR $10 \%, 300 \mathrm{~mm}$ dan tanah dasar CBR $6 \%$.

Dalam Gambar 5 diperlihatkan pengujian lapangan dan test pits di lapangan.

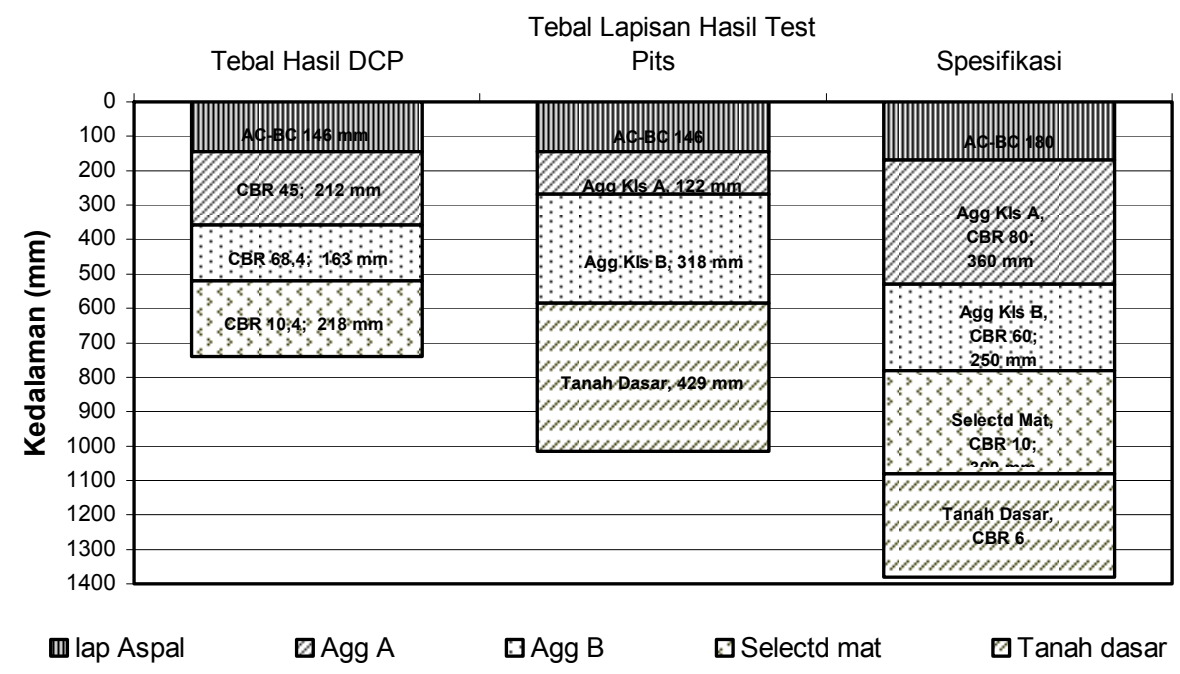

Gambar 4 Spesifikasi dan Tipikal Hasil Pengukuran DCP dan Test Pits 


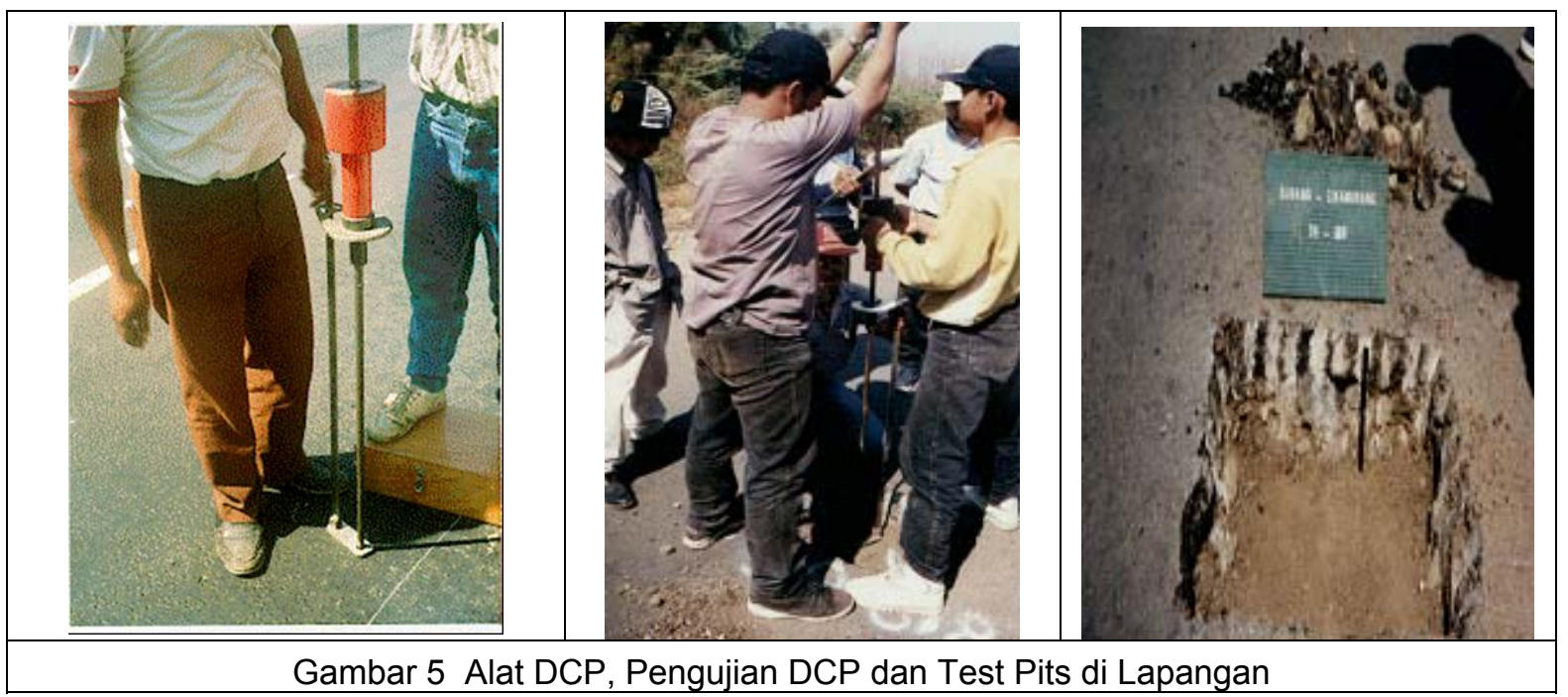

\subsection{Analisis Tebal Agregat - $B$}

Berdasarkan tebal yang ada, dari hasil pengukuran tebal lapis Agg-B sebagai berikut:

$$
\bar{x}=330,2 ; \mathrm{s}=129,1 \mathrm{~cm} ; \mathrm{n}=13
$$

Spesifikasi tebal $\mathrm{L}_{\mathrm{L}}=250 \mathrm{~mm}$

Resiko penerimaan $=5 \%$ (dari tabel distribusi $t$, dengan $n=13$ dan $v=(n-1)=13-1=12$, maka $t$ $=1,782$ )

$\%$ kerusakan yang dapat diterima $=15 \%$

Nilai rata-rata populasi, $\mu$ :

$\mu=\bar{x} \pm t \frac{s}{\sqrt{n}}=330,2-1,782 \frac{129,1}{\sqrt{13}}=266,4$

Hitung \% kerusakan:

$Z^{\prime \prime}=\frac{\mu-L_{L}}{s}=\frac{266,4-250}{129,1}=0,13$

Dari distribusi normal, \% kerusakan $=44,04 \%>$ $15 \%$ (ditolak).

\subsection{Analisis Nilai CBR Agregat - $B$}

Dari hasil analisis DCP dapat diketahui nilai CBR Agg-B, sebagai berikut:

$$
\bar{X}=66,3 ; \mathrm{s}=50 \mathrm{~cm} ; \mathrm{n}=13
$$

Spesifikasi tebal $\mathrm{L}_{\mathrm{L}}=60 \%$

Resiko penerimaan $=10 \%$ (dari tabel distribusi $t$, dengan $n=13$ dan $v=(n-1)=13-1=12$, maka $t$ $=1,356)$

$\%$ kerusakan yang dapat diterima $=15 \%$
Nilai rata-rata populasi, $\mu$ :

$$
\mu=\bar{x} \pm t \frac{s}{\sqrt{n}}=66,3-1,356 \frac{50}{\sqrt{13}}=47,5
$$

Hitung \% kerusakan:

$$
z^{\prime \prime}=\frac{\mu-L_{L}}{s}=\frac{47,5-60}{50}=-0,25 \text { diambil } 0
$$

Dari distribusi normal, $\%$ kerusakan $=48,01 \%>$ 15\% (ditolak).

Berdasarkan hasil analisis tersebut di atas terlihat bahwa pengujian dengan DCP dapat menginterpretasikan berdasarkan data yang ada di lapangan. Walaupun data menunjukkan nilai yang signifikan memenuhi syarat, baik tebal maupun CBR, namun berdasarkan analisa statistik yang menunjukkan deviasi yang besar dapat menghasilkan kinerja yang harus ditolak. Bila diperhatikan dalam tahun-tahun terakhir dapat diketahui bahwa ruas jalan tersebut sering rusak.

\section{KESIMPULAN}

Dari hasil pembahasan dan uraian tersebut di atas, dapat diambil kesimpulan sebagai berikut

a) Dari suatu hasil uji, alat DCP dapat menginterpretasikan kedalaman lapisan perkerasan dan nilai daya dukung CBR yang diukur, serta menguji kesesuaian tebal lapis perkerasan yang diukur dengan uji Tes Pits.

b) Dari hasil uji terlihat bahwa DCP dapat mengidentifikasi sampai kedalaman yang 
diperlukan atau maksimum $120 \mathrm{~cm}$, dengan tebal setiap lapisan sesuai dengan nilai CBR yang diperoleh;

c) Berdasarkan kecepatan perolehan data dan pengalaman lapangan, hasil pengujian dengan alat DCP dapat dicapai sekitar 10 sampai 12 hasil uji per hari untuk 3 lapisan atau lebih, sehingga pengujian DCP adalah 6 kali lebih cepat dari pada pengujian CBR lapangan konvensional.

d) Perbedaan hasil pengukuran dengan test pits dapat terjadi karena lokasi yang diuji dengan DCP tidak persis dilakukan di sekitar lokasi titik uji DCP. Dalam setiap pengukuran pada umumnya tidak diperlukan test pits di setiap titik uji karena akan memakan waktu yang relatif lama, merusak badan jalan, serta memerlukan tambalan;

e) Pengujian dengan alat DCP relatif sangat cepat untuk mengidentifikasi nilai CBR lapis perkerasan jalan yang ada di lapangan, untuk penyelidikan atau pemeriksaan tebal dan daya dukung perkerasan jalan, serta untuk mengukur kesesuaian tebal perkerasan jalan yang telah dilaksanakan oleh penyedia jasa (Kontraktor).

f) Pengujian dengan alat DCP perlu dirumuskan menjadi standar atau pedoman teknis untuk mengidentifikasi nilai CBR lapangan di Indonesia.

\section{DAFTAR PUSTAKA}

1. Austroads (1992). Pavement Design. A guide to the structural design of roads pavements. Australia

2. Dachlan, A. Tatang, Ir, M.Eng.Sc (2000). Laporan Petunjuk Pengoperasian Penetrasi Konus Dinamis. Pusat Litbang Prasarana Transportasi. Bandung

3. Puslitbang Prasarana Transportasi (2002). Laporan Hasil Pengujian, Pekerjaan Peningkatan Jalan North Java Road Improvement Project (NJRIP). Paket AP-04, AP-05 dan AP-06. Jawa Barat. Bandung, Oktober 2002

4. SNI 03-1738-1989. Metode Pengujian CBR Lapangan

5. SNI 03-1744-1989. Metode Pengujian CBR Laboratorium

6. SNI 03-4153-1996. Metode pengujian penetrasi dengan standard penetration tests (SPT)
7. SNI 03-6868-2002, Tata Cara Pengambilan Contoh Uji Secara Acak untuk Bahan-bahan Konstruksi

8. TRL, Overseas Road Note 31 (1993). A guide to the structural design of bitumensurfaced roads in tropical and sub-tropical countries. Transport Research Laboratory. Crowthorne. United Kingdom

\section{BIODATA}

Ir. A. Tatang Dachlan, M.Eng.Sc adalah Ahli Peneliti Muda bekerja di Pusat Litbang Jalan \& Jembatan, Balitbang, Departemen Pekerjaan Umum. Pendidikan terakhir dari UNSW Sydney Australia tahun 1996. Aktif dan ahli dalam bidang bahan dan perkerasan jalan, perencanaan, quality control serta standardisasi. 